\title{
EFEKTIFITAS EKSTRAK UMBI GADUNG (Dioscorea hispida) TERHADAP HAMA ULAT GRAYAK (Spodoptera llitura F.)
}

\author{
Yustina M.S.W. Pu'u ${ }^{1}$, Maria Alacok Mana ${ }^{2}$ \\ Yus_puu@yahoo.com
}

Program Studi Agroteknologi, Fakultas Pertanian-Universitas Flores

\begin{abstract}
This research aims at revealing the effect of yam extract against spodoptera litura pest, and some optimum concentration of yam tuber extract which causes the highest mortality of grayak caterpillar pest.

The design used in this experiment is Complete Randomized Block Design (CRBD) with treatment used is $\mathrm{KO}$ (distilled water), K1, K2, K3, K4. The observation variables in this research are contact poison, nerve poison, stomach poison, and repellent.

The result indicates that yam extract causes mortality in contact poison amounted to $30 \%$, nerve poison amounted to $30 \%$, stomach poison amounted to $30 \%$, and repellent amounted to $23.85 \%$.
\end{abstract}

\section{Key Words: yam tuber extract, grayak caterpillar.}

PENDAHULUAN

Ulat grayak (Spodoptera litura F)

merupakan salah satu jenis hama terpenting yang menyerang tanaman palawija dan sayuran di Indonesia. Hama ini bersifat polifag dan sangat umum sebagai hama tanaman pertanian yaitu selain menyerang tanaman kedelai juga menyerang tanaman kacang tanah, tomat, jagung, kacang hijau, bawang daun, kol dan lain- lain atau mempunyai kisaran inang yang cukup luas atau banyak inang sehingga agak sulit dikendalikan (Susilo, dkk, 1996).

Penurunan tingkat produksi tanaman hortikultura salah satunya disebabkan oleh serangan hama ulat grayak (Spodoptera litura F). Menurut data BPS, (2007) ulat grayak dapat menyerang tanaman hingga mengakibatkan puso. Luas serangan ulat grayak dari tahun 2007 hingga 2008 berkisar antara 1.316 hingga 2.902 ha (Ditlin, 2008). 
Yustina: Efektifitas ekstrak umbi gadung (dioscorea hispida) terhadap hama ulat grayak (Spodoptera llitura F.)

Pengendalian hama ulat grayak

Spodoptera litura F. Pada umumnya

dilakukan dengan penggunaan bahan

kimia, namun penggunaan pestisida

sintetik yang kurang bijaksana telah

menimbulkan berbagai dampak yang

merugikan. Pemanfaatan pestisida

sintetik yang tidak efisien dan efektif

dapat mengakibatkan bahaya besar bagi

ekosistem dan dapat menyebabkan

hama sasaran menjadi resisten,

disamping juga membunuh hewan-

hewan bukan sasaran seperti predator

dan parasitoid (Sudarmo, 1992).

Saat ini mulai diterapkan konsep

Pengelolaan Hama Terpadu PHT yang

dalam penerapannya harus

mempertimbangkaan dampaknya, baik

yang bersifat ekologis, ekonomis, dan

sosiologis sehingga keseluruhan akan

diperoleh hasil yang terbaik. Komponen

PHT yang dianjurkan adalah

penggunaan pestisida nabati

(Oka,1993). Penggunaan pestisida nabati dapat dilaksanakan secara tradisional yang tidak memerlukan keahlian khusus sehingga menjadi terasa lebih mudah dan murah. Keuntungan lain dari penggunaan pestisida nabati adalah tidak meninggalkan residu dalam jaringan tanaman dan lingkungan karena mudah terdegradasi, dengan demikian pestisida nabati merupakan salah satu alternatif yang dapat di harapkan untuk mensubstitusi penggunaan pestisida sintetis yang diharapkan dampaknya lebih ramah terhadap lingkungan dan murah (Tombe, 1999). Salah satu tumbuhan yang berpotensi sebagai pestisida nabati adalah umbi gadung (Dioscorea hispida).

Tanaman gadung (Dioscorea hispida dennst) merupakan tanaman tahunan yang berpotensi sebagai pestisida nabati, karena bagian umbi secara umum mengandung diosgenin, steroid saponin, alkohol dan fenol yang 
Yustina: Efektifitas ekstrak umbi gadung (dioscorea hispida) terhadap hama ulat grayak (Spodoptera llitura F.)

efektif untuk mengendalikan hama ulat grayak. Saponin bersifat racun saraf, racun perut dan antifeedan dan dapat mengendalikan hama tikus, ulat dan hama pengisap. Alkaloid mampu menghambat pertumbuhan dan perkembangan jamur patogen. Tanin, sebagai astrigen yang dapat memperkeras kulit. Tanaman umbi gadung(dioscorea hispida) digunakan sebagai bahan penelitian selain karena kandungannya tanaman ini juga terdapat banyak dan tumbuh liar di kabupaten Ende.

$$
\text { Penelitian sebelumnya }
$$

menyebutkan bahwa LC 50 ekstrak gadung racun terhadap larva ulat grayak instra ke-3 Spodoptera lituraF. adalah $10 \%$, Hasil pra penelitian menunjukan bahwa uji ekstrak umbi gadung dapat menyebabkan kematian Spodoptera litura terbesar yaitu $70 \%$ hal tersebut memperlihatkan bahwa ekstrak umbi gadung lebih efektif dalam menghambat perkembangan Spodoptera litura F.

\section{METODE PENELITIAN}

\section{Waktu dan Tempat}

Penelitian ini dilaksanakan di Laboratorium Fakultas Pertanian Universitas Flores, Waktu penelitian dari bulan April - Juni 2013.

\section{Bahan dan Alat}

Bahan yang dibutuhkan yaitu madu, daun jagung, larva Spodoptera litura $F$. (instar ke 3), aquades dan umbi gadung. Alat yang digunakan yaitu gelas ukur, cawan petri, pipet, toples pembiakan, mikropipet, parut, kain lap, saringan, kertas HVS, spidol dan kamera.

\section{Rancangan Penelitian}

Penelitian ini menggunakan Rancangan Acak Lengkap (RAL) dengan 5 perlakuan yaitu KO (aquades), $\mathrm{K} 1$ = konsentrasi ekstrak umbi gadung $5 \%, \mathrm{~K} 2=$ konsentrasi ekstrak umbi gadung $10 \%, \mathrm{~K} 3=$ kosentrasi ekstrak 
Yustina: Efektifitas ekstrak umbi gadung (dioscorea hispida) terhadap hama ulat grayak (Spodoptera llitura F.)

umbi gadung $15 \%$, dan $\mathrm{K} 4=$ kosentrasi

ekstrak umbi gadung 20\%. Setiap

perlakuan diulang sebanyak 4 kali.

\section{Pelaksanaan Penelitian}

\section{Perbanyakan Ulat Grayak.}

Pembiakan dilakukan dengan cara mengambil larva Spodoptera litura di lapang kemudian dimasukan dalam toples plastik yang berisi pakan daun jagung baru dan dipelihara selama 30 hari. Dengan langkah sebagai berikut, Pembiakan dilakukan dengan cara imago spodopteralitura diambil dari lapanganyang sudah terinfeksi kemudian dimasukan dalam toples plastik yang berisi pakan dann jagung baru yang belum terinfeksi dipelihara selama 30 hari, untuk mendapatkan turunan F1, setelah keturunan F1 didapat, imago dipindahkan ke dalam stoples berisi daun jagung yang belum terinfeksi di pelihara selama 30 hari sampai menghasilkan keturunan F2 dan siap digunakan sebagai bahan perlakuan, Stadium telur berlangsung sekitar 3 hari Telur diletakkan berkelompok dan ditutupi oleh bulubulu halus berwama coklat kemerahan, dan Larva selama 18 hari, sedangkan masa pupa berlangsung 6 hari, Pada masing- masing toples penetasan diberi label ditulis tanggal pembiakan

\section{Proses Pembuatan Ekstrak Umbi}

\section{Gadung.}

Umbi gadung dipilih dengan ukuran yang sama sebanyak $3 \mathrm{~kg}$. kemudian di bersihkan lalu diparut halus, dari hasil parutan tarsebut disaring dengan tujuan memisahkan bahan aktif, hasil ekstrak yang didapatkan sebanyak $150 \mathrm{ml}$, Pengenceran bahan aktif dengan menggunakan aquades dilakukan sesuai perlakuan yaitu KO, (tampa perlakuan), K1, (25 ml ekstrak gadung: $475 \mathrm{ml}$ aquades), K2, (50 ml ekstrak gadung: $450 \mathrm{ml}$ aquades), K3, (75 ml ekstrak Gadung: $425 \mathrm{ml}$ aquades), k4, (100 ml 
Yustina: Efektifitas ekstrak umbi gadung (dioscorea hispida) terhadap hama ulat grayak (Spodoptera llitura F.)

ekstrak gadung) dan diaplikasikan pada Spodopteralitura $\mathrm{F}$.

\section{Pra Penelitian}

Pra Penelitian dilakukan dengan cara ulat grayak sebanyak 5 ekor dimasukan ke dalam toples yang sudah diberi ekstrak dengan konsentrasi KO, K1, K2, K3, dan K4. Setelah itu untuk mengetahui sintasan dari ulat grayak tersebut yang harus di amati adalah berapa lama ulat grayak bertahan hidup tanpa makan dan tanpa pengaruh ekstrak umbi gadung pada konsentrasi KO (K kontrol). Sedangkan untuk menentukan interval waktu pengamatan dilihat padatingkat jumlah mortalitas ulat grayak dalam setiapjam pada konsentarsi K1, K2, K3 dan K4.

\section{Variabel Pengamatan}

1) Mortalitas Racun Kontak (\%)

Aplikasi racun kontak dilakukan dengan cara latutan ekstrak umbi gadung disemprot secara merata keseluruh permukaan toples kemudian dimasukan larva Spodoptera litura $F$. sebanyak 5 ekor SpodopteralituraF, pada setiap perlakuan yang diulang sebanyak 4 kali jadi larva yang dibutuhkan sebanyak 100 ekor Spodopteralítura F. lalu amati setiap 1 jam selama 6 jam, Dengan menghitung mortalitas (\%) Aktivitas racun kontak menurut Prijono (1988) dapat dilihat dari kematian serangga karena pengaruh perlakuan yang mengakibatkan kerusakan pada permukaan tubuh sehingga mengakibatkan mortalitas, yang dinyatakan dalam persentase dan ditentukan dengan menggunakan rumus:

$$
\left(P m=\frac{M s p}{P l a} \times 100 \%\right)
$$

Keterangan:

$\mathrm{Pm} \quad=$ Peningkatan mortalitas (Spodopteralitura F.)\%

Msp = Mortalitas (Spadopteralitura F.) setelah perlakuan

$\mathrm{Pla}=$ Populasi $($ Spodoptera litura $F$. $)$ awal 
Yustina: Efektifitas ekstrak umbi gadung (dioscorea hispida) terhadap hama ulat grayak (Spodoptera llitura F.)

2) Mortalitas Racun Perut (\%)

Pakan (daun jagung) direndam

dalam ekstrak umbi gadung (Discorea

hispida), sesuai perlakuan kemudian

diinfestasikan Spodoptera litura $F$.

sebanyak 5 ekor. Pengamatan uji Racun

Perut dilakukan setiap 1 jam selama 6

jam untuk mengamati mortalitas

Spodoptera litura F.telah diberi

perlakuan, yang dinyatakan dalam

persentase dan ditentukan dengan menggunakan rumus:

$$
P M=\frac{M s p}{P l a} \times 100 \%
$$

Keterangan:

$\mathrm{PM}=$ Peningkatan Mortalitas

Spodopteralitura F. (\%)

Msp = Mortalitas Spodoptera litura F.

setelah perlakuan

Pal = Populasi Spodoptera litura $F$. awal

3) Persentase Kunjungan (\%)

Jumlah populasi yang terbunuh

dalam persentase penurunan aktivitas

makan dengan rumus:

$$
P K=\frac{J K s p}{P a l} \times 100 \%
$$

Keterangan:

$\mathrm{PK}=$ Penurunan Kunjungan $(\%)$

$\begin{array}{lll}\text { JKsp } & =\quad \text { Jumlah }\end{array}$

kunjunganSpodopteralitura $\mathrm{F}$. pada perlakuan

$\mathrm{Pal}=$ Populasi Spadoptera litura F.awal

4) Perubahan Bentuk dan Warna

Perubahan bentuk dan warna dilihat dari ciri-ciri fisik ulat grayak setelah diberi ekstrak umbi gadung dan diamati setiap perlakuan pada masingmasing variabel pengamatan.

\section{Analisis Data}

Data yang sudah dianalísis dan ditrasformási dengan trasformasi archin $\sqrt{x}$ untuk melihat tingkat nyata pengaruh perlakuan dilanjutkan analisis sidik ragam dan apabila perlakuan menunjukkan pengaruh yang nyata maka dilanjutkan dengan uji BNT taraf 5\% (Gomez dan Gomez, 1995) 
Yustina: Efektifitas ekstrak umbi gadung (dioscorea hispida) terhadap hama ulat grayak (Spodoptera llitura F.)

HASIL DAN PEMBAHASAN

Hasil analisis sidik ragam Repelan dan Recun Perut (Tabel 4.1).

menunjukan bahwa ekstrak umbi

gadung berpengaruh terhadap

perkembangan hama ulat grayak pada

Tabel 4.1 Pengaruh ekstrak umbi gadung terhadap aktivitas Racun Kontak, Racun Syaraf, Repelan dan Racun Perut terhadap mortalitas hama SpodopteralituraF

\begin{tabular}{ccccc}
\hline \multirow{2}{*}{ Perlakuan } & $\begin{array}{c}\text { Racun } \\
\text { Kontak }\end{array}$ & $\begin{array}{c}\text { Racun } \\
\text { Perut }\end{array}$ & $\begin{array}{c}\text { Racun } \\
\text { Saraf }\end{array}$ & Repelen \\
\hline KO & $0.00 \mathrm{e}$ & $0.00 \mathrm{e}$ & $0.00 \mathrm{e}$ & $100.00 \mathrm{a}$ \\
K1 & $75.00 \mathrm{~d}$ & $70.00 \mathrm{~d}$ & $80.00 \mathrm{~d}$ & $10.00 \mathrm{~b}$ \\
K2 & $80.00 \mathrm{c}$ & $80.00 \mathrm{c}$ & $85.00 \mathrm{c}$ & $0 \mathrm{c}$ \\
K3 & $90.00 \mathrm{~b}$ & $85.00 \mathrm{~b}$ & $90.00 \mathrm{~b}$ & $0 \mathrm{c}$ \\
K4 & $95.00 \mathrm{a}$ & $90.00 \mathrm{a}$ & $95.00 \mathrm{a}$ & $0 \mathrm{c}$ \\
\hline BNT 5\% & 1.52 & 3.16 & 2.50 & 1.68 \\
\hline
\end{tabular}

Keterangan: angka-angka yang diikali huruf yang sama pada kolom yang sama, berarti tidak berbeda nyata pada. uji BNT taraf 5\%. Data ditransformasi dengan $\operatorname{arcsinu} \sqrt{x}$

Hasil penelitian menunjukkan

bahwa mortalitas hama Spodoptera

litura $\mathrm{F}$ paling tinggi untuk aktivitas

racun kontak, perut dan syaraf pada

perlakuan konsentrasi ekstrak umbi

gadung 20\% (K4) dengan tingkat

mortalitas sebesar $95 \%, 90 \%$, dan 95

\%. Hal ini disebabkan karena dengan

konsentrasi yang tinggi sehingga

kandungan senyawa yang ada dalam

ekstrak tersebut semakin banyak sehingga racun yang mengenai kulit serangga akan berkerja lebih efektif dan menghambat pertumbuhan dan menyebabkan kematian serangga lebih banyak.

Umbi gadung mengandung senyawa Saponin yang memiliki aktivitas racun kontak langsung bekerja ketika terjadi kontak antara serangga. Senyawa tersebut masuk melalui kutikula, trakhea atau langsung 
Yustina: Efektifitas ekstrak umbi gadung (dioscorea hispida) terhadap hama ulat grayak (Spodoptera llitura F.)

mengenai mulut serangga dan menembus integumen. Kneblock (1989) menyatakan bahan aktif yang memiliki sifat daya larut lebih tinggi dalam air akan mudah menembus lapisan fosfolipid membran sel sehingga lebih cepat mengganggu fungsi fisiologis yang pada akhirnya sel akan mengalami kematian. Abdomen merupakan salah satu bagian terpenting dari tubuh serangga, dimana sistemsistem metabolisme dalam tubuh serangga terjadi pada daerah abdomen. Jika bagian abdomen serangga terganggu maka sistem metabolisme serangga juga terganggu. insektisida yang mempunyai efek racun kontak sebagian besar terjadi pada kutikula. Senyawa aktif akan berpenetrasi ke dalam tubuh serangga melalui bagian yang dilapisi oleh kutikula yang tipis, seperti selaput antara ruas, selaput persendian pada pangkal embelan dan kemoreseptor pada tarsus.
Tanaman gadung mengandung senyawa saponin, Alkaloid, tanin yang memiliki kemampuan sebagai antiseptik, yang berfungsi untuk mencegah pertumbuhan mikroorganisme dan memiliki fungsi yaitu mempengaruhi fungsi saraf dengan menghambat enzim kolinesterase, sehingga akan terjadi gangguan transmisi rangsang yang menyebabkan kematian bagi larva yang berkembang menjadi serangga dewasa. Ekstrak tanaman gadung memiliki aroma yang menyegat. Aroma tersebut terdeteksi oleh serangga spodopteralitura melalui organ penerima rangsang, dan dapat mempengaruhi kunjungan serangga tersebut terhadap daun jagung yang diberi perlakuan dan menyebabkan kematian pada serangga tersebut.

Mekanisme kerja senyawa aktif dalam ekstrak gadung adalah dengan menghambat selera makan atau 
Yustina: Efektifitas ekstrak umbi gadung (dioscorea hispida) terhadap hama ulat grayak (Spodoptera llitura F.)

menolak makan serangga atau hama.

Berkurangnya selera makan dari

serangga tersebut tidak berkemampuan

untuk merusak hasil panen baik dengan

cara memakan dan mengerat sehingga

mengakibat kematian serangga apabila

dalam waktu yang cukup lama terus

mengalami kontak dengan serangga

tersebut.

Hasil menunjukkan bahwa aktivitas kunjungan (repellen) hama $S$.

litura F. pada perlakuan aquades (KO) menunjukkan kunjungan yang paling tinggi. Kondisi ini menyebabkan jumlah makanan yang tersedia banyak tanpa ada senyawa beracun sehingga daya sintasan hama semakin tinggi. Sedangkan perlakuan konsentrasi ektrak umbi gadung $20 \%$ (K4) menunjukkan tidak ada aktivitas kunjungan hama $S$. litura F. Hal ini disebabkan karena adanya kandungan senyawa yang mampu menolak serangga karena mengandung tanin dimana zat ini bersifat repellent bagi serangga karena baunya yang tidak disenangi sehingga hama tidak mendekati inang tersebut.

Ekstrak gadung mengandung senyawa tanin yang dapat berperan sebagai repellent (penolak serangga)dan antifeedent (penolak makan). Zat yang terkandung dalam gadung menimbulkan rasa ketidaksukaan pada serangga. Sehingga untuk memperoleh kelangsungan hidupnya maka serangga harus mencari tempat yang sesuai, dengan cara keluar dari bahan yang diberi perlakuan ekstrak gadung tersebut. Semakin banyak konsentrasi ekstrak gadung yang diberikan maka daya tolaknya terhadap serangga pun akan lebih tinggi.

\section{Kesimpulan}

1. Ekstrak umbi gadung (Dioscorea hispida) berpengaruh nyata terhadap mortalitas hama Spodoptera litura F. pada aktivitas sebagai racun kontak sebesar $95 \%$, 
Yustina: Efektifitas ekstrak umbi gadung grayak (Spodoptera llitura F.)

racun perut sebesar $90 \%$, racun

syaraf sebesar $95 \%$, dan repellen 0

$\%$

2. Konsentrasi ekstrak umbi gadung

$20 \%$ menyebabkan mortaitas hama

Spodoptera litura F. sebesar $95 \%$.

\section{Ucapan Terima Kasih}

Pada kesempatan ini penulis ingin mengucapkan terima kasih kepada semua pihak yang telah membantu dengan caranya masing-masing dalam melengkapi tulisan ini.

\section{DAFTAR PUSTAKA}

Arnason, J. T. S. Mackinno, Al 1993. Balai Besarperbenihan dan ProteksiTanamanPerkebunan

Ambon. Direkorat Jenderal Perkebunan- Kementerian Pertanian.

http://administrator.web.Ditjenbun@de ptan.go.id

BadanPusatStatistik.

2007.

SurveiPertanian. Luas dan

Intensitas Serangga Ulat Gerayak di Sumbar. Sumbar: Badan Pusat Statistik.

Dir. Perlind. Tanaman. 2008. Laporan Luas dan Serangan Hama dan Penyakit Tanaman Hama di Indonesia. Direktorat Perlindungan tanaman Pangan. Jakarta.

http://www.bps.go.id/tab/view.php?tabe l=1\&id_subyek $=53 \&$ notan $=32$ (dioscorea hispida) terhadap hama ulat

Direktorat BPTP dan Ditjenbun. 1994. Balai BesarPerbenihan dan ProteksiPertanianPerkebunan Ambon. DirektoratJenderalPerkebunanKem entrianPertanian.

http://administrator.web.ditjenbun@dep tan.go.id

Gomez dan Gomez, 1995. AnalisisSidikRagamDengan Uji BNT 5\%.

Herbisan-Evans, D. and S. Crossley. 2009. SpodopteraLitura (Fabricius, 1775) clustercaterpilar, amphirynae, nouctidae, http:///www_staff.it.uts.edu.au/don/ larva/arco/litura/html. $\quad 16$ September 2009.

Marwoto. 1996. Pengendalian Hama DaunKedelaiDenganInsektisidadan FeromonoidesksUlatGrayak. PenelitianPertanianTanamanPanga

Marwoto dan Sudarsono. 2008. StrategidanKomponenTeknologiPe ngendalianUlatGrayak (Spodoptera Litura Fabricius) Pada Tanaman Kedelai.

Novizan.Ir. 2004. Membuat dan Memanfaatkan Pestisida Ramah Lingkungan. Kanisius. Yogyakarta.

Oka, I. N. 1995. Pengendalian Hama TerpadudanImplementasinya di Indonesia.Yogyakarta : Gajah Mada University Press.

Prijono. 1994. Pengujian Insektisida: Penuntun Praktikum Jurusan Hama dan Penyakit Tumbuhan, Fakultas Pertanian. Bogor :InstitutPertanian Bogor.

Pustekom. 2008. Klasifikasi dan Bioekologi Ulat Grayak (Spodoptera Litura F.) http://bp4k.blogorkab.go.id./index. php?option=comcontent $\&$ view $=$ articie $\& i d=77$ : seran gan-ulat-grayak-padacabe \&catid $=41$ : berita $\&$ iteid $=59$ diakses 17 Juli 2012. 
Yustina: Efektifitas ekstrak umbi gadung (dioscorea hispida) terhadap hama ulat grayak (Spodoptera llitura F.)

Susilo, A., D.Haryanto, dan S. Satriyo. 1996. Pengaruh Bagian Tanaman

Mimba (AzadiractaIndica) terhadap Mortalitas Ulat Grayak (Spodoptera Litura F.). Majalah Ilmiah Pembangunan 5 (9): 136: 143. Diakses pada tanggall4 mei 2012 .

Sudarmo, S. 1992. Pestisida Untuk Tanaman. Yogyakarta: Kanisius.

Tombe, M. 1999. Pengenalan dan Peranan Fungisida Nabati dalam Pengendalian Penyakit Tanaman. Dalam: Amrizal M. Rivai dan Iwa Mara Trisawa (penyunting). Perkembangan Teknologi Tanaman Rempah dan Obat 11 (2) : 16-23

Wiratno.1993. Penelitian Pendahuluan Pengaruh Beberapa Konsentrasi Eugenol Terhadap Mortalitas Stegobium Paniceum. Pp.56-59. Dalam: Sitepu, Pasril Wahid, M. Soehadjoan, S. Rusli, dan D. Soetopo (penyunting) Prosiding Seminar Hasil Penelitian Dalam Rangka Pemanfaatan Pestisida Nabati, Bogor: 1-2 Desember 1993.

Yunisman, dkk. 2010. Uji Efikasi Ekstrak Gadung Racun (Dioscorea hispida Deanst) Terhadap Ulat Grayak (Spadoptera exigua Hubner)

(http://repository.unand.ac.id/1369/ 1/absk_pertanian_10.doc) 